\title{
Selenium-Containing Preparation Use for Athletes' Adaptive Abilities to Physical Loads Improvement
}

\author{
Shuvalova N.V. \\ I.Ya. Yakovlev State Pedagogical University \\ Cheboksary, Russia \\ msta77@yandex.ru
}

\author{
Drandrov G.L. \\ I.Ya. Yakovlev State Pedagogical University \\ Cheboksary, Russia \\ gerold49@mail.ru
}

\author{
Lezhenina S.V. \\ I.N. Ulyanov State University \\ Cheboksary, Russia \\ svl-8@bk.ru
}

\begin{abstract}
The aim of the research work is to study the influence of selenium-containing and other (neotone and panangin) preparations on athletes' adaptive abilities to physical loads improvement. 90 boys at the age of 17-19 took part in the research. They went in for athletics and had the $1^{\text {st }}$ and the $2^{\text {nd }}$ sports categories. It was stated that the athletes from the experimental group, who took selmevit, neotone and panangin during 30 days, had considerably better competitive results during $\mathbf{3 0 0 0}$ meters distance overcoming, in hemoglobin indices and the amount of erythrocytes in blood. We came to the conclusion that in case of long-term (till 30 days) selmevit, neotone and panangin use there happens athletes' organism adaptation to physical and psycho-emotional loads and also balance normalization between prooxidation and antioxidation parameters of antioxidative defence system and there is transfer from short-term adaptation to long-term adaptation.
\end{abstract}

Keywords-metabolic preparations; adaptive abilities of an organism; athletes; antioxidative system; selenium.

\section{INTRODUCTION}

Many spheres of a man's industrial activity are connected with intensive psycho-emotional and physical loads, which have negative influence on health. It especially concerns sports activity. Constant sports result increase is connected with great physical loads during training and high psycho-emotional tension during competitions. Professional sport politicization, commercialization and many other factors place high demands on an athlete's organism. Very often an athlete undergoes high loads. They increase his adaptive abilities and it leads to adaptation disruption, to extreme physical and psycho-emotional loads and finally to pathological states development.

In terms of the sport rejuvenation tendency the problems of the training and competitive process maintenance became more urgent. Early sports specialization, intensive physical loads during early age training, together with knowledge accumulation concerning genetic determinants and external factors influence on athletes' health state condition the necessity to control the state of athletes' cardiovascular system, as one of the main factors providing adaptation to physical stress.

Chuvash Republic is the region with high risk of selenium lack, which has negative influence on health state of population. In terms of deficient these or that micro- and macroelements morpho-physiological status correction of all age groups by means of deficient components of the ration is reasonable [5], especially among people with the increased physical and psycho-emotional load.

Special literature analysis helped to suppose, that one of the most effective techniques of working capacity renewal and increase among athletes can become allowed in sports medicine preparations use.

That is why the aim of our research work was the influence study of a complex Selenium-containing preparation and other preparations (neotone and panangin) taking on athletes' adaptive abilities to physical loads improvement.

\section{RESEARCH METHODOLOGY}

90 boys at the age of 17-19 took part in the research. They went in for athletics and had the 1st and the 2nd sports categories ("racewalking" specialization). According to the results of individual medical cards there were no pathological deviations in cardiovascular, digestive and nervous systems. The respondents didn't have congenital diseases [2].

The respondents were divided into two groups. The control group (45 people) included athletes, who didn't take Selenium-containing preparation and other preparations (neotone and panangin).

The experimental group (45 people) included athletes, who took Selenium-containing preparation and other preparations (neotone and panangin) every day. 
Both groups trained 30 days according to the increased and regulated scheme of the loads, which included the following: $20 \mathrm{~km}$ running, 60 min walking with speed $1 \mathrm{~km}$ $5,20 / 5,50,10 \mathrm{~min}$ walking with speeding up $71 \mathrm{~m}$ in $142 \mathrm{~m}$, general physical training (GPT) exercises (shoulder dip, legs lifting at a bar, chin-up, 60-70 degrees press), 25 minutes of gymnastics (joints mobility development) [1,3].

In the experimental group additional health-improving events were held together with Selenium-containing preparation taking and taking into account the content of bioadditive, which was the composition of selenopiranum (SP), vitamin C, vitamin E and optimizing students' adaptation owing to intensity bio-balance of free radical oxidation processes (FRO) and antioxidant system (AOS) activity.

It was taken into account that the components of bioadditive influence different stages of organic peroxides creation: tocopherols prevent gender owing to intensity of $\mathrm{SH}$-group membrane proteins oxidation decrease; glutathione peroxidase decomposes existing peroxides of lipids and hydrogen. Together with ascorbate $\alpha$ - tocopherol provides selenium inclusion into an active center of glutathione peroxidase $[6,7,8,9,10,11]$.

\section{RESULTS}

It is stated (table I) that in the experimental group athletes, who took selmevit, neotone and panangin during 30 days had significant results increase of 3000 meters distance overcoming (for 18,1 s - from 905,4 till 887,3 s), than in the control group (for 5,3 s - from 902,8 till 897,5 s).

TABLE I. TIME OF 3000 METERS DIST ANCE OVERCOMING BY MEANS OF RACEWALKING AMONG BOYS FROM THE CONTROL AND EXPERIMENTAL GROUP BEFORE AND AFTER THE PEDAGOGICAL EXPERIMENT, $\mathrm{S}(\mathrm{X} \pm \Sigma)$

\begin{tabular}{|c|c|c|c|}
\hline \multirow{2}{*}{$\begin{array}{l}\text { Groups of } \\
\text { respondents }\end{array}$} & \multicolumn{2}{|c|}{$\begin{array}{l}\text { Time of } 3000 \text { meters distance } \\
\text { overcoming, } s\end{array}$} & \multirow[t]{2}{*}{$\mathrm{P}$} \\
\hline & $\begin{array}{l}\text { Before the } \\
\text { experiment }\end{array}$ & $\begin{array}{l}\text { After the } \\
\text { experiment }\end{array}$ & \\
\hline Control, $\mathrm{n}=45$ & $902,8 \pm 21,6$ & $897,5 \pm 18,7$ & $>0,05$ \\
\hline Experimental, $\mathrm{n}=45$ & $905,4 \pm 15,3$ & $887,3 \pm 11,5$ & $<0,05$ \\
\hline $\mathrm{P}$ & $>0,05$ & $<0,05$ & \\
\hline
\end{tabular}

Table II presents hemoglobin indices in blood of athletes before and after the experiment.

At the beginning of the experiment these indices among the respondents of both groups were different: control group - 146,6 g/l, experimental group - 145,7 g/l.

During the experiment these indices among athletes from the control group preserved the same - $147,7 \mathrm{~g} / \mathrm{l}$. In the experimental group there were higher hemoglobin indices $154,4 \mathrm{~g} / \mathrm{l}$. The differences were statistically valid in terms of $\mathrm{P}<0,05$.
TABLE II. HEMOGLOBIN INDICES AMONG ATHLETES FROM THE CONTROL AND EXPERIMENTAL GROUPS BEFORE AND AFTER THE PEDAGOGICAL EXPERIMENT, G/L $(\mathrm{X} \pm \Sigma)$

\begin{tabular}{|c|c|c|c|}
\hline \multirow{2}{*}{$\begin{array}{l}\text { Groups of } \\
\text { respondents }\end{array}$} & \multicolumn{2}{|c|}{ Indices } & \multirow[t]{2}{*}{$\mathrm{P}$} \\
\hline & $\begin{array}{l}\text { Before the } \\
\text { experiment }\end{array}$ & $\begin{array}{l}\text { After the } \\
\text { experiment }\end{array}$ & \\
\hline Control, $n=45$ & $146,6 \pm 3,14$ & $147,7 \pm 2,74$ & $>0,05$ \\
\hline Experimental, $\mathrm{n}=45$ & $145,7 \pm 2,83$ & $154,4 \pm 2,68$ & $<0,05$ \\
\hline $\mathrm{P}$ & $>0,05$ & $<0,05$ & \\
\hline
\end{tabular}

Table III presents indices of erythrocytes concentration in blood of athletes before and after the experiment. Comparative analysis of these indices, observed before the experiment, didn't reveal considerable differences - in the control group they were $4,96 \times 10^{12} / 1$, in the experimental group- $4,87 \times 10^{12} / 1$. After the experiment athletes from the experimental group had significant advantage in these indices - $5,26 \times 10^{12}$ vs $4,92 \times 10^{12} / 1$.

TABLE III. THE INDICES OF ERYTHROCYTES CONCENTRATION

IN BLOOD AMONG ATHLETES FROM THE CONTROL AND EXPERIMENTAL GROUPS BEFORE AND AFTER THE PEDAGOGICAL EXPERIMENT, G/L $(\mathrm{X} \pm \Sigma)$

\begin{tabular}{|c|c|c|c|}
\hline \multirow{2}{*}{$\begin{array}{l}\text { Groups of } \\
\text { respondents }\end{array}$} & \multicolumn{2}{|c|}{ Indices } & \multirow[t]{2}{*}{$\mathrm{P}$} \\
\hline & $\begin{array}{l}\text { Before the } \\
\text { experiment }\end{array}$ & $\begin{array}{l}\text { After the } \\
\text { experiment }\end{array}$ & \\
\hline Control, $\mathrm{n}=45$ & $4,96 \times 10^{12}$ & $4,87 \times 10^{12}$ & $>0,05$ \\
\hline Experimental, $\mathrm{n}=45$ & $4,92 \times 10^{12}$ & $5,26 \times 10^{12}$ & $<0,05$ \\
\hline $\mathrm{P}$ & $>0,05$ & $<0,05$ & \\
\hline
\end{tabular}

As our research work showed, selenium deficiency prophylaxis provides regulatory mechanisms tension decrease and biologically more effective adaptation to high physical and psycho-emotional loads [5].

There were several attempts of algorithm creation of metabolic effect preparations taking in case of this or that variant of disadaptative heart changes among athletes.

We can present our variant of metabolic means choice during stress cardiomyopathy prophylaxis and cure (table IV).

The list of the presented by us preparations would be increased. However, the presented preparations are already widely used during heart disorders cure and prophylaxis among athletes and are the important reserve of young athletes' tolerance increase concerning intensive physical loads.

TABLE IV. METABOLIC EFFECT PREPARATIONS CHOICE DURING DIFFERENT VARIANTS OF HEART DISORDERS AND PATHOLOGICAL CHANGES PREVENTION AMONG ATHLETES (ALGORITHM)

\begin{tabular}{|c|c|c|c|c|}
\hline $\begin{array}{c}\text { Pharmacolo } \\
\text { gical group }\end{array}$ & $\begin{array}{c}\text { Repolarization } \\
\text { process violation at } \\
\text { ECG }\end{array}$ & $\begin{array}{c}\text { Heart rate and } \\
\text { cardial } \\
\text { conduction } \\
\text { disorder }\end{array}$ & $\begin{array}{c}\text { Systolic } \\
\text { and } \\
\text { diastolic } \\
\text { dysfunctio } \\
\text { n }\end{array}$ & $\begin{array}{c}\text { Myocardial } \\
\text { hypertrophy }\end{array}$ \\
\hline $\begin{array}{c}\text { Antioxidant } \\
\mathrm{s}\end{array}$ & $\begin{array}{c}\text { Vitamin complex with } \\
\text { antioxidant(selenium) } \\
\text { "selmevit", coenzyme } \\
\text { Q-10 }\end{array}$ & $\begin{array}{c}\text { "Selmevit", } \\
\text { coenzyme Q- } \\
10\end{array}$ & $\begin{array}{c}\text { "Selmevit" } \\
\text { coenzyme } \\
\text { Q-10 }\end{array}$ & $\begin{array}{c}\text { "Selmevit", } \\
\text { coenzyme Q- } \\
10\end{array}$ \\
\hline $\begin{array}{c}\text { Antihypoxa } \\
\text { nts }\end{array}$ & $\begin{array}{c}\text { Cytochrome C, } \\
\text { vitamin K }\end{array}$ & $\begin{array}{c}\text { Hypoxen, } \\
\text { Cytochrome } \\
\text { C, vitamin K }\end{array}$ & $\begin{array}{c}\text { Cytochrom } \\
\text { e C, } \\
\text { vitamin K }\end{array}$ & $\begin{array}{c}\text { Cytochrome C, } \\
\text { vitamin K }\end{array}$ \\
\hline $\begin{array}{c}\text { Potassium } \\
\text { and } \\
\text { magnesium } \\
\text { preparations }\end{array}$ & $\begin{array}{c}\text { Asparcamum, } \\
\text { panangin }\end{array}$ & $\begin{array}{c}\text { Asparcamum, } \\
\text { panangin }\end{array}$ & & \\
\hline $\begin{array}{c}\text { Energy- } \\
\text { saving }\end{array}$ & $\begin{array}{c}\text { Creatine, } \\
\text { niboxinum, }\end{array}$ & $\begin{array}{c}\text { Creatine, } \\
\text { Riboxinum, } \\
\text { neotone }\end{array}$ & $\begin{array}{c}\text { Creatine, } \\
\text { Riboxinum } \\
\text { neotone }\end{array}$ & $\begin{array}{c}\text { Creatine, } \\
\text { Riboxinum, } \\
\text { neotone }\end{array}$ \\
\hline
\end{tabular}




\section{IV.CONCLUSION}

Held by us experimental work showed that in case of complex selenium correction of organism adaptation there is balance normalization between prooxidation (malondialdehyde, oxidized glutathione, gender activity decrease) and anti-oxidation (vitamins $\mathrm{E}$ and $\mathrm{A}$ concentration, renewed glutathione, catalase, glutathione peroxidase, selenium, AOS activity increase) parameters of antioxidative defence system and there is transfer from short-term adaptation to long-term adaptation. As a results, in age-related aspect there are metabolic (general protein concentration increase, iodine, glucose, calcium level stabilization), immune (hemopoiesis activation, the level of A-, M-, G-immunoglobulin increase), somatometric (body weight increase) effects.

\section{References}

[1] Balykova L.A., Markelova I.L. Approaches to pathologic changes of heart diagnostics and correction among young athletes using metabolic effect preparations. Practical medicine. Cardiology: scientific works collection. 2010, pp. 67-72.

[2] Gavrilova E.A. Sports heart; stress cardiomyopathy. Moscow: Soviet sport. 2007, 200.

[3] Zemtsovskiy E.V. Sports cardiomyopathy. Saint-Petersburg: Hippocrates. 1995.

[4] Korneeva I.T., Polyakov S.D., Petrichuk S.V. The opportunities of physical load correction by means of metabolic effect preparations among young athletes. Materials of the International scientificpractical conference "Ecology and health of children in Russia". Smolensk. 2000, pp. 74-75.

[5] Nikulina A.V. Adaptation improvement of junior students to higher education conditions. Human.Sport.Medicine. 2019, vol. 19, S1, pp. 68-761

[6] Bosello-Travain, V., Conrad M., Cozza G. et al. Protein disulfide isomerase and glutathione are alternative substrates in the one Cys catalytic cycle of gluta-thione peroxidase 7. Biochimica et BiophysicaActa (BBA). General Subjects. 2013, vol. 1830, pp. 38463857.

[7] Dong, Yu., Zhang Ziwei, Yao Hai-dong. Antioxidative role of selenoprotein $\mathrm{W}$ in oxidant-induced chicken splenic lymphocyte death. BioMetals. 2014, vol. 27, pp. 277-291.

[8] Gao, J., Liu Y., Huang Y. et al. Daily selenium intake in a moderate selenium deficiency area of Suzhou, China. Food Chem. 2011, vol. 126, pp. 1088-1093.

[9] Hanif, S.H. Muhammed Influence of Menstrual Cycle on Maximal Aerobic Power of Young Female Adults. AJPARS. 2011, vol. 3, 1, pp. 36-41.

[10] Traber, M.G., Stevens J.F. Vitamins C and E: Beneficial effects from a mechanistic perspective. Free Radical Biology and Medicine. 2011, vol. 51, 5, pp. 1000-1013.

[11] Kuznetsova Z.M., Kuznetsov S.A., Ovchinnikov Yu.D., Golovko P.V. Analysis of the morphological-functional indices connection degree in throwing among athletes. The Russia Journal of Physical Education and Sport. 2018, 13(2), pp. 43-50. DOI: 10.14526/02_2018_308.

[12] Alexsandr S. Kuznetsov. Russian Professor's meeting. Russian Journal of Physical Education and Sport. 2019, 14(1), pp. 17-22. DOI: 10.14526/2070-4798-2019-14-1-18-24

[13] Zhang, Q., Van der Donk W.A., Radical-Mediated W. Enzymatic Methylation: A Tale of Two SAMs. Acc. Chem. Res. 2012, vol. 45, pp. 555-564. 